\title{
Parachordoma: A Recurrent Case and Review of the Literature
}

\section{Parakordoma: Nükseden Bir Olgu Nedeniyle Literatürün Gözden Geçirilmesi}

\author{
Yeliz ARMAN KARAKAYA, Selver ÖZEKINCi, Hüseyin BÜYÜKBAYRAM, Bülent MIZRAK
}

Department of Medical Pathology, Dicle University, Faculty of Medicine, DIYARBAKIR, TURKEY

\begin{abstract}
Parachordoma is an uncommon tumor of soft tissue, and the origin is not clear. Recurrence and metastasis are rarely seen. A piecemeal mass measuring $7 \times 4 \times 3 \mathrm{~cm}$ was excised from a 28 -year-man who had presented with pain and swelling of the right shoulder for 5 years. Histopathologically, the tumor was composed of cells with clear eosinophilic cytoplasm and an epithelioid appearance in a myxoid stroma separated by fibrous tissue with mild pleomorphism and mitotic activity. Tumoral cells were immunoreactive for cytokeratin 8/18, EMA, S-100 and vimentin, immunohistochemically. Recurrence was seen one year after the initial diagnosis. Areas of increased mitotic activity and atypical mitoses were observed in the recurrent tumor. We report this case as recurrence occurred earlier than usual and exhibited malignant features.
\end{abstract}

Key Words: Parachordoma, Myoepithelioma, Diagnosis Differential

\section{ÖZ}

Parakordoma yumuşak dokunun nadir görülen bir tümörüdür. Kökeni tam olarak açılanamamıştır. Nüks azdır, geç dönemde görülür ve nadiren metastaz yapar. 5 yıldır sağ omzunda ağrı ve şişlik şikayeti olan 28 yaşındaki erkek hastadan, $7 \times 4 \times 3 \mathrm{~cm}$. boyutlarında parçalı olarak kitle eksize edilmiştir. Mikroskopik değerlendirmede, tümörün fibröz doku ile ayrılmış miksoid stromada, şeffaf eozinofilik sitoplazmalı epiteloid görünümde, şekil ve büyüklük farkı gösteren, mitotik aktivitesi orta derecede olan hücrelerden oluştuğu izlenmiştir. CK8/18, EMA, S-100, vimentin ile boyanma izlenmiştir. Olgumuzda ilk tanıdan bir yıl sonra nüks görülmüştür. Nüks tümörün, invaziv olduğu, mitotik aktivitesinin yüksek olduğu, atipik mitozlar içerdiği izlenmiştir. Olgu, nüksün erken dönemde olması ve histopatolojik incelemede malign özellikler içermesinden dolayı sunulmaktadır.

Anahtar Sözcükler: Parakordoma, Myoepitelyoma, Ayırıcı tanı

\section{INTRODUCTION}

Parachordomas are soft tissue tumors that do not have a definite known origin. The 2002 World Health Organization (WHO) classification has included parachordomas in the same class as mixed tumors and myoepitheliomas (1). Parachordomas have first been defined by Laskowski as a peripheral chordoma and Dabska has published a 10-case series in 1977 (2). The largest published series consists of 101 cases (3).

\section{CASE REPORT}

A 28-year-old male presented to the Diyarbakir State Hospital Orthopedics Outpatients Department with a mass and pain of the right shoulder for 5 years and increasing symptoms for the last 2 months. There was a swelling of the right shoulder at the acromion region. Magnetic Resonance Imaging revealed a $4 \times 1.5 \mathrm{~cm}$ septated cystic lesion with

Received : 25.12 .2010

Accepted : 16.03 .2011 smooth borders at a subacromial/subdeltoid localization that compressed the deltoid and supraspinatus muscles. The mass was excised. Macroscopic examination revealed pieces of tissue grayish in color with irregular borders and a piecemeal appearance. The section surface was grayish with a solid appearance and contained scattered myxoid areas. Microscopically the tumor consisted of a collagenous and fibromyxoid stroma and oval to round pleomorphic cells in an epithelioid appearance with a clear cytoplasm and occasional vacuoles. A moderate degree of mitotic activity was noted. Reticular nodular pattern, an adenoid-like structure and cords in a focal manner were seen (Figure 1). The tumor cells stained with cytokeratin (CK) 8/18 (Figure 2), S-100 (Figure 3), Pan CK, Epithelial Membrane Antigen (EMA) (Figure 4) and vimentin but did not stain with thyroglobulin, chromogranin-A, HMB-45, Melan-A or Glial Fibrillary Acidic Protein (GFAP). A parachordoma/ mixed tumor diagnosis was made.

Correspondence: Yeliz ARMAN KARAKAYA

Department of Medical Pathology, Dicle University, Faculty of Medicine, DIYARBAKIR, TURKEY

E-mail: yelizkarakaya20@hotmail.com Phone: +90 5052774160 


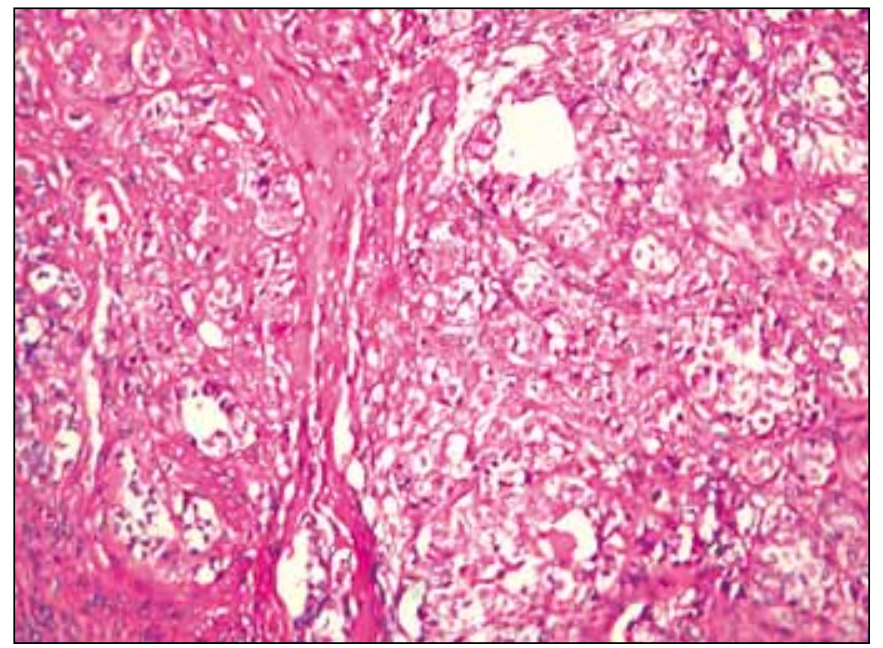

Figure 1: Reticulonodular growth pattern (H\&E, x200).

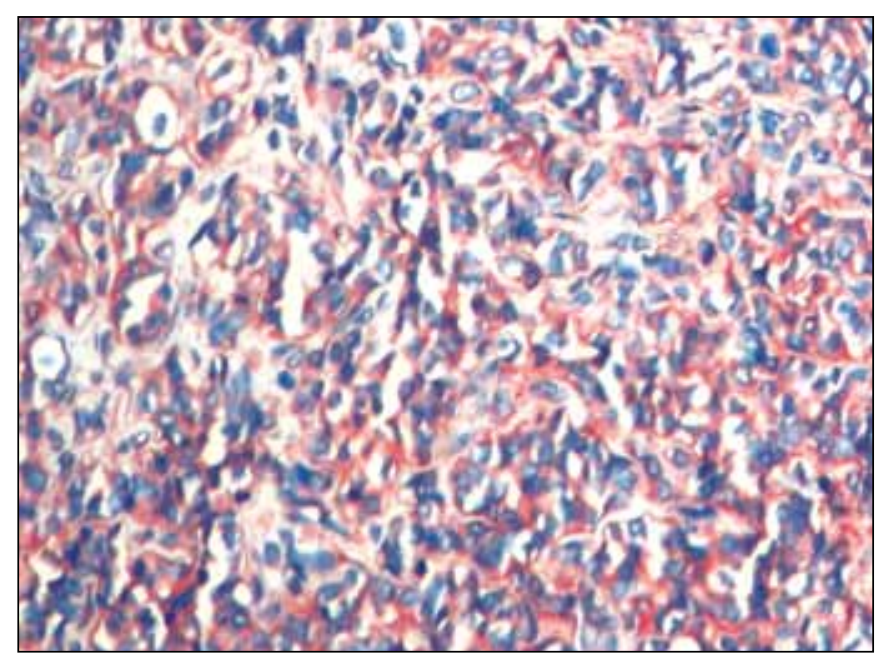

Figure 3: S-100 positivity in tumor cells (x100).

The patient presented at the Dicle University Medical Faculty Orthopedics Outpatients Department a year later with similar symptoms. A preliminary diagnosis of recurrent parachordoma was made and the mass was excised. The recurrent tumor's microscopy revealed marked atypical features, pleomorphism and a high degree of mitotic activity. The first pathology material had 2-3 mitoses/10 hpf while this value was 6-7 mitoses/10 hpf in the recurrent pathology material. A diagnosis of recurrent parachordoma was made. Close follow-up was suggested due to the marked atypical findings. The patient was healthy on 18-month follow-up.

\section{DISCUSSION}

Parachordomas are usually seen in adults but the 101-case series has reported an age range of 3 to 83 with a mean age of 39 (4). Our case is 28 years old and younger than the

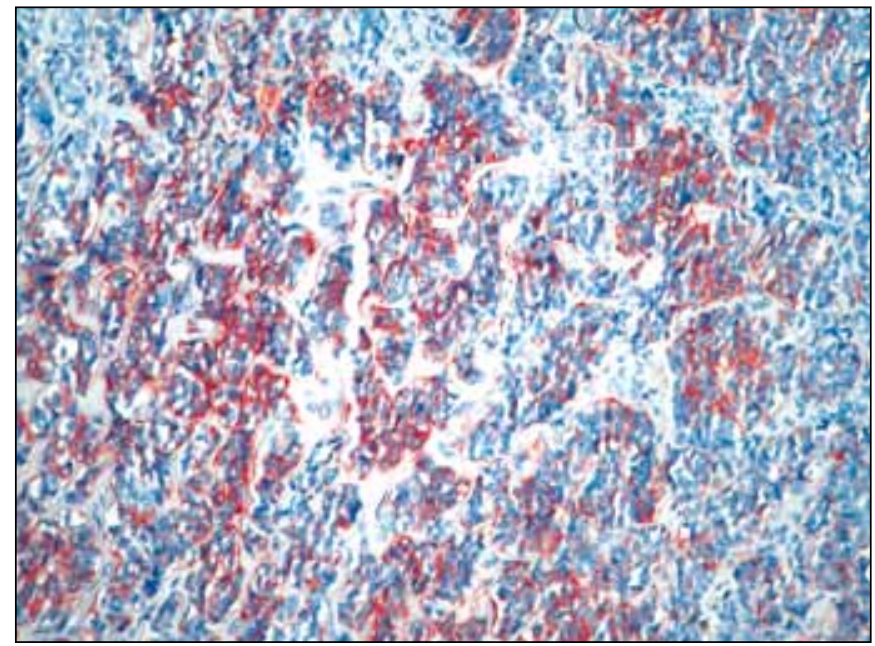

Figure 2: CK8/18 positivity in tumor cells (x100).

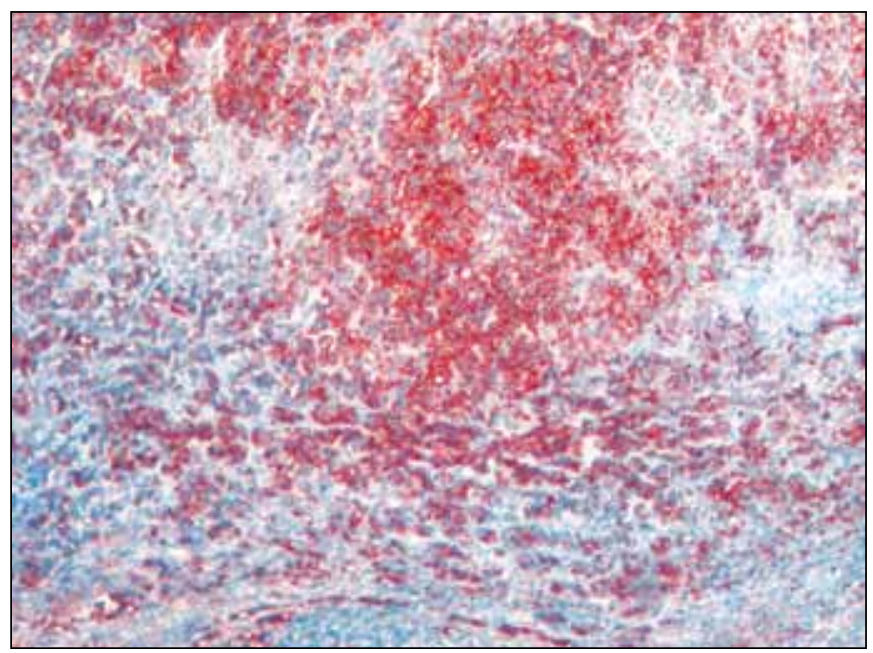

Figure 4: EMA positivity in tumor cells (x100).

mean age reported by the literature. The lesion is reported to be seen more commonly in males. The lower extremities are the most usual location (5). The location in the 101case series was distributed as the lower extremity in 41 , upper extremity in 35, head and neck in 15 and the body in 10. Our case was male and the tumor had a shoulder localization (3).

Parachordomas are usually painless tumors and are encountered as slow-growing masses (4). However, two painful cases with a subperiosteal location have been reported. The tumor was painful in our case and this was the reason for presentation. The tumor is well-limited and sometimes surrounded by a thin fibrous pseudocapsule. It

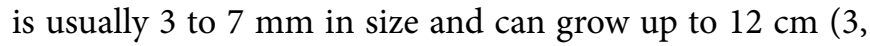
4). Our tumor was $7 \times 4 \times 3 \mathrm{~cm}$ in size. The section surface was shiny with a myxoid or gelatinous appearance, similar 
to other reports. Resection usually results in cure, and recurrences and metastases are rare (5). Our case had a recurrence one year later. There are reports of a forearm parachordoma with lung metastasis (6) and a chest wall parachordoma with lymph node metastasis in the literature. Metastatic tumors are more cellular and the cells are more pleomorphic (7).

There are various theories about the histogenetic origin of parachordomas but there is no widely accepted view. They have been said to develop from progenitor cells with a chondroid differentiation capacity, the bone surface associated with tenosynovial or aponeurotic tissue or the periosteum, or subcutaneous tissues (4). Parachordomas are thought to be related with ectopic notochord remnants, synovial tumors including synovial sarcomas and lipoblasts and chondroblasts. Most authors believe myoepithelial cell origin (8-9).

Low magnification reveals that the tumor consists of small nests of epithelioid cells, cords and pseudoglandular structures, together with a myxohyaline stroma. The proliferating cells have an abundant clear, pale eosinophilic cytoplasm similar to the physaliphorus cells of classical chordoma. The myxoid material is defined by intracytoplasmic vacuoles. Intracytoplasmic glycogen is demonstrated by PAS staining. The nucleus may vary from vesicular chromatin and prominent nucleoli to a small pyknotic form. Multinucleation is usually present. Mitotic activity is minimal. There is no lymphatic or vascular invasion. Some parachordomas have spindle cells with narrow cytoplasm and hyperchromatic nuclei arranged in cords and surrounded by a fibrous matrix. The stromal matrix can vary from pure myxoid to chondroid or hyalinelike composition (4).

This group of tumors show morphological heterogeneity The differential diagnosis depends on the dominant cell type and stromal component and includes extraskeletal myxoid chondrosarcoma, chordoma, ossified fibromyxoid tumor, metastatic carcinoma, clear cell sarcoma, metastatic malignant melanoma and epithelioid sarcoma. Extraskeletal myxoid chondrosarcoma shows eosinophilic spindle cell cords that create multinodular patterns and ovoid cells within a myxoid matrix, and generally extends to the deep skeletal muscle. Extraskeletal myxoid chondrosarcomas have smaller cells that are more intensely eosinophilic with a less vacuolated cytoplasm than parachordoma cells (4). Some extraskeletal myxoid chondrosarcoma cases stained with S-100 (1). Parachordomas generally express CK and especially CK8/18, while CK expression is not seen in extraskeletal myxoid chondrosarcomas (1). Chordomas of sacral and vertebral location are seen in older patients and have a higher risk of recurrence due to both their histological characteristics and difficulty of achieving total surgical excision (10). The microscopical features of chordomas and parachordomas are not very similar but a chondroid matrix is relatively rarer in parachordomas (1). Our case was differentiated from a papillary thyroid carcinoma, indicated by the clear cells, with the negative thyroglobulin staining. Epithelioid sarcomas frequently express $\mathrm{CK}$ and EMA but S-100, GFAP and myogenic markers are negative. Melanomas typically express melanocytic antigens such as Melan-A, HMB-45 and S-100 (1).

There are contradictory views on the surgical margins and recurrence association in the literature. Surgical treatment can provide a cure in parachordoma but tumors that have not been fully excised can recur (4). Our case also had a recurrence a year later. There is no clear relationship between the status of the surgical margins and local recurrence but local recurrences and metastases are more frequent in patients with a histologically malignant appearance (1). A pediatric myoepithelial carcinoma series in the literature has reported recurrence in 9 of 17 cases with negative surgical margins (11). The specimen was piecemeal in our case and we were unable to evaluate the surgical margins. The histopathological appearance of the case indicated malignancy. Suggesting the cause of recurrence. There are reports of a forearm parachordoma with lung metastasis (6) and a chest wall parachordoma with lymph node metastasis in the literature. Metastatic tumors are more cellular and the cells are more pleomorphic (7). Necrotic areas and nuclear atypia have been seen in metastatic tumors (12).

Parachordomas are benign tumors but metastases and recurrences are not unusual. Dabska (2) has reported recurrences after 7,2 and 12 years later but Niezabitowski et al. (13) have reported a recurrence at 3 months, Carstens et al. at 6 months and Ishida et al. (14) at 1 year although early recurrence is rare. However, it is difficult to determine the mean rate of recurrence due to the difficulty of a long time follow-up (5). Two deaths from metastatic parachordoma have been reported in the literature and it has been said that parachordomas may potentially be low-grade sarcomas (5). Parachordomas are benign tumors but they can become malignant when recurrence occurs after a short period and cases should therefore be followed-up closely. 


\section{REFERENCES}

1. Weiss SW, Goldblum JR: Enzinger \& Weiss's Soft Tissue Tumors. 5th ed., Philadelphia, Mosby Elsevier, 2008, 1109-1116

2. Dabska M: Parachordoma: a new clinicopathologic entity. Cancer 1977, 40:1586-1592

3. Hornick JL, Fletcher CD: Myoepithelial tumors of soft tissue: a clinicopathologic and immunohistochemical study of 101 cases with evaluation of prognostic parameters. Am J Surg Pathol 1997, 27:1183-1196

4. Silverberg SG, DeLellis RA, Frable WJ, LiVolsi VA, Wick MR: Silverberg's Principles and Practice of Surgical Pathology and Cytopathology. 4th ed., Philadelphia, Churchill Livingstone, 2006, 395-396

5. Clabeaux J, Hojnowski L, Valente A, Damron TA: Case report: parachordoma of soft tissues of the arm. Clin Orthop Relat Res 2008, 466:1251-1256

6. Guedes A, Barreto BG, Barreto LG, de Oliveira Araújo IB, Queiroz AC, Athanazio DA, Athanazio PR: Metastatic parachordoma. J Cutan Pathol 2009, 36:270-273

7. Limon J, Babińska M, Denis A, Ryś J, Niezabitowski A: Parachordoma: a rare sarcoma with clonal chromosomal changes. Cancer Genet Cytogenet 1998, 102:78-80
8. Kilpatrick SE, Hitchcock MG, Kraus MD, Calonje E, Fletcher CD: Mixed tumors and myoepitheliomas of soft tissue: a clinicopathologic study of 19 cases with a unifying concept. Am J Surg Pathol 1997, 21:13-22

9. O'Connell JX, Berean KW: Parochordomas. Am J Surg Pathol 1997, 21:1120-1121

10. Sarsık B, Doğanavşargil B, Başdemir G, Zileli M, Sabah D, Öztop F: Chordomas: Is it possible to predict recurrence? Turk Patoloji Derg 2009, 25:27-34

11. Gleason BC, Fletcher CD: Myoepithelial carcinoma of soft tissue in children: an aggressive neoplasm analyzed in a series of 29 cases. Am J Surg Pathol 2007, 31:1813-1824

12. Abe S, Imamura T, Harasawa A, Ishida T, Unno K, Tateishi A, Tokizaki T, Yorikawa J, Matsushita T: Parachordoma with multiple metastases. J Comput Assist Tomogr 2003, 27:634-638

13. Fisher C, Miettinen M: Parachordoma: a clinicopathologic and immunohistochemical study of four cases of an unusual soft tissue neoplasm. Ann Diagn Pathol 1997, 1:3-10

14. Ishida T, Oda H, Oka T, Imamura T, Machinami R: Parachordoma: an ultrastructural and immunohistochemical study. Virchows Arch A Pathol Anat Histopathol 1993, 422: 239-245 